OPEN ACCESS

Edited by:

Manuel Kleiner,

University of Calgary, Canada

Reviewed by:

Barry Shane,

University of California, Berkeley, USA

Maddalena Rossi,

University of Modena and Reggio

Emilia, Italy

Jean Guy LeBlanc,

CERELA-CONICET, Argentina

${ }^{*}$ Correspondence:

Michael Rychlik

michael.rychlik@tum.de

Specialty section

This article was submitted to Microbial Physiology and Metabolism,

a section of the journal

Frontiers in Microbiology

Received: 28 November 2016 Accepted: 03 March 2017

Published: 21 March 2017

Citation:

Kopp M, Dürr K, Steigleder M,

Clavel T and Rychlik M (2017)

Measurements of Intra- and Extra-Cellular 5-Methyltetrahydrofolate

Indicate that Bifidobacterium Adolescentis DSM $20083^{T}$ and Bifidobacterium Pseudocatenulatum DSM 20438T Do Not Actively Excrete

5-Methyltetrahydrofolate In vitro.

Front. Microbiol. 8:445.

doi: 10.3389/fmicb.2017.00445

\section{Measurements of Intra- and} Extra-Cellular 5-Methyltetrahydrofolate Indicate that Bifidobacterium Adolescentis DSM $20083^{\top}$ and Bifidobacterium Pseudocatenulatum DSM 20438' ${ }^{\top}$ Do Not Actively Excrete 5-Methyltetrahydrofolate In vitro

\author{
Markus Kopp ${ }^{1,2}$, Kerstin Dürr ${ }^{1}$, Matthias Steigleder ${ }^{1}$, Thomas Clavel ${ }^{2,3}$ and \\ Michael Rychlik ${ }^{1 *}$ \\ ${ }^{1}$ Chair of Analytical Food Chemistry, Technische Universität München, Freising, Germany, ${ }^{2}$ ZIEL Institute for Food and \\ Health, Core Facility Microbiome/NGS, Technische Universiät München, Freising, Germany, ${ }^{3}$ Institute of Medical \\ Microbiology, RWTH University Hospital, Aachen, Germany
}

Certain intestinal bifidobacteria have the ability to synthesize folates. In vitro experiments revealed a high production, cellular accumulation, and release of reduced folate vitamers like 5-methyltetrahydrofolate and tetrahydrofolate in folate-free medium (FFM). However, it is still unclear to which extent synthesized folates are polyglutamylated and probably not available for transport, and if they are actively released by excretion. To address these questions, we characterized intra- and extra-cellular pteroylmonoglutamates and polyglutamylated 5-methyltetrahydrofolate $\left(5-\mathrm{CH}_{3}-\mathrm{H}_{4} \mathrm{PteGlu}_{2}-4\right)$ in Bifidobacterium adolescentis DSM 20083 ${ }^{\top}$ and Bifidobacterium pseudocatenulatum DSM $20438^{\top}$ in vitro. Folates were measured by means of stable isotope dilution assays (SIDA) coupled with LC-MS/MS analysis using $\left[{ }^{2} \mathrm{H}_{4}\right]-5$-methyltetrahydrofolic acid, $\left[{ }^{2} \mathrm{H}_{4}\right]$-tetrahydrofolic acid, and $\left[{ }^{2} \mathrm{H}_{4}\right]-5$-formyltetrahydrofolic acid as internal standards. Cell viability was examined by fluorescence microscopy. Quantitation of folate production by $B$. adolescentis during the stationary phase revealed a linear increase of dead cells paralleled by increasing concentration of 5-formyltetrahydrofolate and 5-methyltetrahydrofolate $\left(100 \% 5-\mathrm{CH}_{3}-\mathrm{H}_{4} \mathrm{PteGlu}_{4}\right)$ in FFM, whereas the intracellular concentrations of these vitamers remained constant. After $24 \mathrm{~h}, \mathrm{~B}$. adolescentis (125 mg cells, wet weight) produced a total amount of $0.846 \mathrm{nmol} 5-\mathrm{CH}_{3}-\mathrm{H}_{4}$ folate: $0.385 \pm 0.059 \mathrm{nmol}(46 \pm$ $7 \%$ ) and $0.461 \pm 0.095 \mathrm{nmol}(54 \pm 11 \%)$ measured in the intracellular (viable cells; 52 $\pm 3 \%$ measured by fluorescence microscopy) and extracellular (lysed cells; $48 \pm 3 \%$ ) fraction, respectively. For B. pseudocatenulatum (124 mg cells, wet weight), $1.135 \mathrm{nmol}$ 
$5-\mathrm{CH}_{3}-\mathrm{H}_{4}$ folate was produced after $24 \mathrm{~h}$, and a similar proportionality between intra- and extra-cellular folate concentrations and viable/lysed cells was observed. These results indicate that the strains tested produce and accumulate $5-\mathrm{CH}_{3}-\mathrm{H}_{4} \mathrm{PteGlu}$ for cellular metabolism, and that extracellular concentrations of the vitamer arise from cell lysis.

Keywords: bifidobacteria, gut microbiota, folate synthesis, folate bioavailability, stable isotope dilution assay, LC-MS/MS

\section{INTRODUCTION}

To the best of our knowledge, only a few attempts have been made to characterize folate production patterns by bifidobacteria in vitro: Pompei et al. (2007) analyzed the intra- and extra-cellular total folate content after $48 \mathrm{~h}$ cultivation in folate-free media (FFM) by quantifying the growth of folate-dependent bacteria in a so-called microbiological assay (MA). D'Aimmo et al. (2012) investigated intracellular folate production and folate patterns in certain bifidobacteria strains by high performance liquid chromatography coupled with UV and fluorescence detection (HPLC-UV/FD). The latter authors identified $5-\mathrm{CH}_{3}-\mathrm{H}_{4}$ folate (structures of folate vitamers, see Figure $\mathrm{S} 1$ ) and $\mathrm{H}_{4}$ folate as main vitamers accumulated by cells cultivated in FFM.

We recently developed a stable isotope dilution assay (SIDA) coupled with LC-MS/MS for sensitive quantitation of the main folate vitamers accumulated and released by Bifidobacterium adolescentis DSM $20083^{\mathrm{T}}$, including $5-\mathrm{CH}_{3}-\mathrm{H}_{4}$ folate, 5-HCO$\mathrm{H}_{4}$ folate, $\mathrm{H}_{4}$ folate, and 5- $\mathrm{CH}_{3}-\mathrm{H}_{4} \mathrm{PteGlu}_{2-4}$ (Kopp et al., 2016). Moreover, we found that the major portion of native $5-\mathrm{CH}_{3}$ $\mathrm{H}_{4}$ folate vitamer was present as its tetraglutamate (>95\%) intraand extra-cellularly. Concentrations of mono-, di-, tri-, and penta-glutamylated folates were below limit of detection (LOD) or limit of quantitation (LOQ).

From these results, the question arose about the possible origin of extracellular folates and particularly polyglutamylated forms. According to the literature (Deguchi et al., 1985; Pompei et al., 2007), intracellularly synthesized folate vitamers can be excreted into the cultivation medium. However, this hypothesis has to date not been tested experimentally and appears very unlikely as folate vitamers with three or more glutamate residues are fully retained by cells based on observations in Lactobacillus casei (Shane and Stokstad, 1975). Extracellular folates may indeed originate from intracellular folates, but without being actively excreted and rather via liberation from bacterial cells after their death and desintegration.

To test this hypothesis, microbiological, and analytical methods were applied to quantify folates and cell viability using pure cultures of B. adolescentis DSM $20083^{\mathrm{T}}$ and Bifidobacterium pseudocatenulatum DSM $20438^{\mathrm{T}}$. We examined intra- and extra-cellular native polyglutamate patterns as well as pteroylmonoglutamate concentrations after deconjugation of polyglutamates, and calculated the absolute amount [nmol] of monoglutamate in cell biomass and defined volumes of FFM. If the assumptions of passive release were correct, two criteria have to be fulfilled: (criterion 1) the intra- and extra-cellular degree of vitamer-specific polyglutamylation with three (retention in cells occurs with a minimum of three glutamate residues) or more glutamate residues should be identical and (criterion 2) the ratio of the absolute intra- and extra-cellular amounts compared to the total amount produced should reflect the relative viability of the strains. In this regard, dead (i.e., not cultivable) but intact cells might still be able to produce folates and, thus have to be considered as viable cells. For confirmation the relative viability was determined by fluorescence microscopy as independent microbiological method.

\section{MATERIALS AND METHODS}

\section{Chemicals}

All chemicals used for cultivation of bifidobacteria, reagents for extraction, and LC-MS/MS solvents have been published earlier (Kopp et al., 2016). Rat serum (preservative free) was obtained from Biozol (Eching, Germany). Chicken pancreas was purchased from Becton Dickinson and Co. (Sparks, MD, USA). $5-\mathrm{CH}_{3}-\mathrm{H}_{4}$ folate, 5-formyltetrahydrofolic acid (5-HCO- $\mathrm{H}_{4}$ folate) calcium salt, and $\mathrm{H}_{4}$ folate trihydrochloride were purchased from Schircks Laboratories (Jona, Switzerland). The isotopologic standards $\left[{ }^{2} \mathrm{H}_{4}\right]-5-\mathrm{CH}_{3}-\mathrm{H}_{4}$ folate, $\left[{ }^{2} \mathrm{H}_{4}\right]-5-\mathrm{HCO}-\mathrm{H}_{4}$ folate, and $\left[{ }^{2} \mathrm{H}_{4}\right]-\mathrm{H}_{4}$ folate were synthesized as reported recently (Freisleben et al., 2002). 5- $\mathrm{CH}_{3}-\mathrm{H}_{4} \mathrm{PteGlu}_{2-4}$ were synthesized according to Ndaw et al. (2001).

\section{Materials}

Strata strong anion exchange (SAX) cartridges (100 mg, $1 \mathrm{~mL}$ ) were obtained from Phenomenex (Aschaffenburg, Germany). AnaeroGen 2.5 L (GasPak) was obtained from Oxoid (Hampshire, UK). Chemicals for FFM were mixed according to D'Aimmo et al. (2012). LIVE/DEAD BacLight Bacterial Viability Kit L7012 for fluorescence microscopy was obtained from Molecular Probes (Eugene, Oregon, USA). For fluorescence microscopy we used an Axiostar plus (HBO 50) microscope with a red BP 546/12; FT 580; LP 590 and a green BP 475/40; FT 500; BP 530/50 fluorescence filter from Carl Zeiss Microimaging GmbH (Göttingen, Germany). Zirconium beads $(0.1 \mathrm{~mm})$ were obtained from Carl Roth $\mathrm{GmbH}$ (Karlsruhe, Germany). The bead beater Fast Prep 24 was manufactured by MP Biomedicals (Solon, OH, USA). Petri plates were purchased from Sarstedt (Nümbrecht, Germany). The HLC Thermomixer was manufactured by DITABIS AG (Pforzheim, Germany).

\section{Cultivation of Bifidobacteria}

B. adolescentis DSM $20083^{\mathrm{T}}$ and B. pseudocatenulatum DSM $20438^{\mathrm{T}}$ were obtained in dried form from the German Collection of Microorganisms and Cell Cultures (DSMZ, Braunschweig, Germany). 
All glass devices and materials were autoclaved prior to use. Experiments were carried out under a laminar flow cabinet. Incubation of the anaerobic bacteria in Falcon tubes was carried out in an anaerobic jar with activated GasPak (Oxoid). MRS medium consisted of $26 \mathrm{~g}$ MRS bouillon in $487.5 \mathrm{~mL}$ water and was autoclaved at $121^{\circ} \mathrm{C}$ for $20 \mathrm{~min}$. A volume of $12.5 \mathrm{~mL} 2 \%$ $(\mathrm{w} / \mathrm{v}) \mathrm{L}$-cysteine solution was added as reducing agent. For longterm storage, bacteria were stored at $-80^{\circ} \mathrm{C}$ in filter-sterilized glycerol $(20 \% \mathrm{w} / \mathrm{v})$ in MRS. Chemicals for FFM medium were mixed according to D'Aimmo et al. (2012).

For each experiment, one cryo-aliquot $(200 \mu \mathrm{l})$ was inoculated into $25 \mathrm{~mL}$ medium and incubated for $24 \mathrm{~h}$ at $37^{\circ} \mathrm{C}$. Afterwards, $1.25 \mathrm{~mL}$ was used for inoculating fresh medium to a final dilution ratio of $5 \%$ (preculture). After $24 \mathrm{~h}$ at $37^{\circ} \mathrm{C}$, the working culture was prepared by diluting $0.5 \mathrm{~mL}$ preculture into $9.5 \mathrm{~mL}$ medium. The working culture was incubated for further $24 \mathrm{~h}$ at $37^{\circ} \mathrm{C}$ prior to extraction.

\section{Folate Extraction}

\section{Solutions for Folate Extraction}

Extraction buffer consisted of a $200 \mathrm{mmol} \cdot \mathrm{L}^{-1}$ MES hydrate and $20 \mathrm{~g} \cdot \mathrm{L}^{-1}$ ascorbic acid aqueous solution with $1 \mathrm{~g} \cdot \mathrm{L}^{-1}$ DTT, adjusted to $\mathrm{pH} 5$ with $7.5 \mathrm{M} \mathrm{NaOH}$. Phosphate buffer (100 $\mathrm{mmol} \cdot \mathrm{L}^{-1}$ ) was prepared by adjusting an aqueous solution of disodium hydrogen phosphate $\left(100 \mathrm{mmol} \cdot \mathrm{L}^{-1}\right)$ with an aqueous solution of potassium dihydrogen phosphate $\left(100 \mathrm{mmol} \cdot \mathrm{L}^{-1}\right)$ to $\mathrm{pH}$ 7.0. The equilibration buffer for the SAX cartridges was prepared by adding $0.2 \mathrm{~g} \cdot \mathrm{L}^{-1}$ DTT to diluted phosphate buffer $\left(10 \mathrm{mmol} \cdot \mathrm{L}^{-1}\right)$. Further, the eluting solution was a mixture of aqueous sodium chloride (5\%) and aqueous sodium acetate $\left(100 \mathrm{mmol} \cdot \mathrm{L}^{-1}\right)$ containing 1 $\mathrm{g} \cdot \mathrm{L}^{-1}$ DTT and ascorbic acid (1\%). The chicken pancreas suspension for pteroylpolyglutamate deconjugation to the pteroyldiglutamates was prepared by stirring chicken pancreas (30 $\mathrm{mg})$ in aqueous phosphate buffer solution $(90 \mathrm{ml}, 100$ $\mathrm{mmol} \cdot \mathrm{L}^{-1}$ ) containing $1 \%$ ascorbic acid adjusted to $\mathrm{pH} 7$ with $7.5 \mathrm{M} \mathrm{NaOH}$. Rat serum was used for pteroyldiglutamate deconjugation to the monoglutamates without further dilution.

\section{Extraction Procedure}

Bacteria suspension (culture volume $10 \mathrm{~mL}$ ) was centrifuged at $5000 \mathrm{~g}$ for $10 \mathrm{~min}$ at $21^{\circ} \mathrm{C}$. The supernatant was subjected to the extraction protocol below, whereas the cellular fraction was suspended in $2 \mathrm{~mL}$ of sterile water and divided into two aliquots. Aliquot 1 was subjected to fluorescence microscopy (Section Determination of Relative Viability by Fluorescence Microscopy), aliquot 2 was resuspended in $4 \mathrm{~mL} \mathrm{PBS}$, centrifuged for $15 \mathrm{~min}$ at $5000 \mathrm{~g}$ and $4^{\circ} \mathrm{C}$. The supernatant was discarded and cellular fraction was resuspended in $10 \mathrm{~mL}$ extraction buffer and subjected to monoglutamate or polyglutamate extraction as described recently (Kopp et al., 2016).

Endogenous folate was determined by performing the extraction procedure for intra- and extra-cellular pteroylmonoglutamates by replacing the sample by $1 \mathrm{~mL}$ of distilled water. Endogenous folate was subtracted from all relevant values after LC-MS/MS measurement.

\section{LC-MS/MS}

Extra- and intra-cellular pteroylmono- and pteroylpolyglutamates were determined separately by means of LC-MS/MS according to our method described previously (Kopp et al., 2016).

\section{Determination of Relative Viability by Fluorescence Microscopy}

For determination of viable and dead cell counts, working cultures were incubated at $37^{\circ} \mathrm{C}$ for $24 \mathrm{~h}$. The LIVE/DEAD BacLight Bacterial Viability Kit, which consists of SYTO 9 (3.34 $\mathrm{mM}$ in DMSO) and propidium iodide (20 $\mathrm{mM}$ in DMSO), was used. After incubation, bacterial suspensions were centrifuged at $5000 \mathrm{~g}$ for $10 \mathrm{~min}$. Pellets were re-suspended in $2 \mathrm{~mL}$ of sterile distilled water. One milliliter of the suspension was diluted in $20 \mathrm{~mL}$ distilled water and left to stand for $60 \mathrm{~min}$ at room temperature. The suspension was shaken after 15, 30, and 45 min. The sample was subsequently centrifuged for $10 \mathrm{~min}$ at $5000 \mathrm{~g}$ at $21^{\circ} \mathrm{C}$. After resuspension in $20 \mathrm{~mL}$ distilled water and further centrifugation, the pellet was diluted in $10 \mathrm{~mL}$ of sterile water. One milliliter was mixed with $3 \mu \mathrm{L}$ of the color mixture consisting of SYTO 9 and propidium iodide $(50 / 50 \mathrm{v} / \mathrm{v})$. The cells were incubated at room temperature in the dark for $15 \mathrm{~min}$. Three aliquots were counted four times each under a microscope with a green (BP 475/40; FT 500; BP 530/50) and red (BP 546/12; FT 580; LP 590) fluorescence filter.

Relative viabilities [\%] were calculated by dividing green (viable) and red (dead) cells by the total cell count multiplied by 100 . Initial viabilities at $\mathrm{t}_{0}=0 \mathrm{~min}$ (removal from medium) were calculated from the values obtained from fluorescence microscopy $\left(\mathrm{t}_{1}\right)$ using the strain-specific calibration functions for mortality during sample preparation (see Supplementary Section S1, Table S1, and Figure S2). Therefore, the duration of the washing step in distilled water was considered, i.e., the time $\left(t_{1}-t_{0}\right)$ between removing the culture from FFM and fluorescence microscopy.

\section{Extra- and Intra-Cellular Folate Production of $B$. adolescentis DSM $20083^{\top}$ during Stationary Phase}

Growth of B. adolescentis DSM $20083^{\mathrm{T}}$ was determined by drop plate method to identify the stationary phase (see Supplementary Section S2). Six working cultures of $B$. adolescentis were incubated at $37^{\circ} \mathrm{C}$. After $15,19,23,37,41$, and $45 \mathrm{~h}$, a single culture was removed and extracted in triplicate according to the procedure described above (Section Extraction Procedure). The respective amount of dead cells was determined by fluorescence microscopy (Section Determination of Relative Viability by Fluorescence Microscopy).

\section{Characterization of Folate Production by $B$. adolescentis DSM $20083^{\top}$ and \\ B. pseudocatenulatum DSM $20438^{\top}$}

To clarify whether $5-\mathrm{CH}_{3}-\mathrm{H}_{4}$ folate is excreted into the medium or originates from cell lysis, we determined the degree of $5-\mathrm{CH}_{3}-$ $\mathrm{H}_{4}$ folate polyglutamylation, intra- and extra-cellular $5-\mathrm{CH}_{3}$ $\mathrm{H}_{4}$ folate and the percental amount of viable and dead cells by 
fluorescence microscopy. Growth of B. pseudocatenulatum DSM $20438^{\mathrm{T}}$ was recorded using the drop plate technique to determine a defined time point for accurate sampling (see Supplementary Section S2).

One working culture of each strain was incubated for $24 \mathrm{~h}$ at $37^{\circ} \mathrm{C}$. Supernatant and cellular fraction were separated as described above (Section Extraction Procedure). After resuspension in $2 \mathrm{~mL}$ of distilled water, $1 \mathrm{~mL}$ of the cellular fraction was subjected to fluorescence microscopy. The remaining aliquot and the supernatant were analyzed in triplicate for monoglutamate and polyglutamate patterns according to the extraction procedure (Section Extraction Procedure). After LC-MS/MS analysis $5-\mathrm{CH}_{3}-\mathrm{H}_{4}$ folate and $5-\mathrm{CH}_{3}-\mathrm{H}_{4} \mathrm{PteGlu}_{2-4}$ patterns were compared to calculate the percental amount of each polyglutamate. Relative viability and relative mortality were calculated on the basis of the cellular fraction suspended in $2 \mathrm{~mL}$ distilled water (Section Determination of Relative Viability by Fluorescence Microscopy) and the supernatant (total volume of $10 \mathrm{~mL}$ ) using $5-\mathrm{CH}_{3}-\mathrm{H}_{4}$ folate (A) as marker compound:

$$
\begin{aligned}
& n(A, \text { intracellular, } L C / M S)[\mathrm{nmol}] \\
& +n(A, \text { extracellular, LC/MS })[n m o l] \\
& =n(A, \text { total }, L C / M S)[\text { nmol }] \\
& \frac{n(A, \text { intracellular, LC } / M S)[\mathrm{nmol}]}{n(A, \text { total }, L C / M S)[n m o l]} * 100 \% \\
& =\text { relative viability (calculated) [\%] (after } 24 \mathrm{~h}) \\
& 100 \% \text { - relative viability (calculated) [\%] } \\
& =\text { relative mortality (calculated) [\%] (after } 24 \mathrm{~h})
\end{aligned}
$$

In analogy we calculated the intra- and extra-cellular amount of $5-\mathrm{CH}_{3}-\mathrm{H}_{4}$ folate from the total amount of $5-\mathrm{CH}_{3}-\mathrm{H}_{4}$ folate by multiplication with the corrected, percental viable and dead cell count (see Supplementary Section S1) obtained from fluorescence microscopy (FM).

$$
\begin{aligned}
& n(A, \text { total, LC/MS })[\text { nmol }]^{*} \text { relative viability }(F M)[\%] \\
& =n(A, \text { intracellular }, \text { calculated })[n m o l] \\
& n(A, \text { total }, L C / M S)[\text { nmol }] \\
& \quad-n(A, \text { intracellular, calculated })[n m o l] \\
& =n(A, \text { extracellular, calculated })[\text { nmol }]
\end{aligned}
$$

\section{Data Analysis}

Data analysis was carried out using the Xcalibur Software version 2.0 (Thermo Scientific, Waltham, USA). Student's $t$-test was used for statistical comparisons, with $p<0.05$ as threshold for significance.

\section{RESULTS}

Bacteria like $L$. casei have been well-characterized for intracellular folate accumulation, retaining pteroylpolyglutamates with three or more glutamate residues (Shane and Stokstad, 1975). In contrast, mono- or di-glutamylated folates may pass the cell membrane. To test the hypothesis that extracellular folate is solely a remnant of cell lysis, two experiments were performed. We examined extracellular enrichment and intracellular accumulation of $5-\mathrm{HCO}-\mathrm{H}_{4}$ folate, $\mathrm{H}_{4}$ folate, $5-\mathrm{CH}_{3}-$ $\mathrm{H}_{4}$ folate and its polyglutamylated analogs $\left(5-\mathrm{CH}_{3}-\mathrm{H}_{4} \mathrm{PteGlu}_{2-4}\right)$ in $B$. adolescentis DSM $20083^{\mathrm{T}}$ during the stationary phase. Furthermore, we investigated the folate production and release by $B$. adolescentis DSM $20083^{\mathrm{T}}$ and $B$. pseudocatenulatum DSM $20438^{\mathrm{T}}$ after $24 \mathrm{~h}$ cultivation using $5-\mathrm{CH}_{3}-\mathrm{H}_{4}$ folate and $5-\mathrm{CH}_{3}-$ $\mathrm{H}_{4} \mathrm{PteGlu}_{2-4}$ as marker compounds for cellular transport.

\section{Extra- and Intra-cellular Folate Production of $B$. adolescentis DSM $20083^{\top}$ during the Stationary Phase}

Results from the growth experiment of $B$. adolescentis DSM $20083^{\mathrm{T}}$ in FFM showed a fast adaption to the synthetic medium which is depicted by the short lag-phase from 0 to $3 \mathrm{~h}$ (Figure 1A).

The stationary phase was reached after $11.5 \mathrm{~h}$ and viable cell counts remained constant after $15 \mathrm{~h}$. In the following experiment, the ratio of dead cells showed a linear increase from 15 to $45 \mathrm{~h}$ during the stationary phase (Figure 1B), confirming that steady state conditions were applied for folate analysis. As the stationary phase is characterized by a constant number of viable cells and an increasing number of dead cells, folate content should increase in the extracellular fraction and remain approximately constant in cells according to our hypothesis. As depicted in Figures 1C-F, we measured the three main monoglutamylated folate vitamers and $5-\mathrm{CH}_{3}-\mathrm{H}_{4} \mathrm{PteGlu}_{4}$, identified as the predominant polyglutamylated $5-\mathrm{CH}_{3}-\mathrm{H}_{4}$ folate in both cells and FFM (Kopp et al., 2016), between 15 and $45 \mathrm{~h}$ of incubation. The further vitamer $5-\mathrm{HCO}-\mathrm{H}_{4}$ folate (Figure 1F) showed curve shape and concentrations similar to that of $5-\mathrm{CH}_{3}-$ $\mathrm{H}_{4}$ folate. For the least stable folate vitamer, $\mathrm{H}_{4}$ folate, we observed a significant decrease $(P<0.05)$ intracellularly during steady state conditions (Figure 1E).

\section{Characterization of Folate Production by $B$. adolescentis DSM $20083^{\top}$}

One culture of $B$. adolescentis DSM $20083^{\mathrm{T}}$ was examined for intra- and extra-cellular $5-\mathrm{CH}_{3}-\mathrm{H}_{4}$ folate and $5-\mathrm{CH}_{3}$ $\mathrm{H}_{4} \mathrm{PteGlu}_{2-4}$ after $24 \mathrm{~h}$ incubation in FFM. 5- $\mathrm{CH}_{3}-\mathrm{H}_{4}$ folate and $5-\mathrm{CH}_{3}-\mathrm{H}_{4} \mathrm{PteGlu}_{2-4}$ were used as marker compounds for folate accumulation and release because of their chemical stability compared to $\mathrm{H}_{4}$ folate and $5-\mathrm{HCO}-\mathrm{H}_{4}$ folate, which tend to be oxidized or interconverted. Our primary goal was to clarify whether folate is transferred into the medium by either excretion or cell lysis. Therefore, we compared the amount of extra- and intracellular $5-\mathrm{CH}_{3}-\mathrm{H}_{4}$ folate obtained from direct measurement by SIDA LC-MS/MS with the amount of folate as extrapolated from relative cell viability measured (see Section Materials and Methods).

The term "monoglutamate" is used below in connection with the total amount of the respective vitamer after enzymatic deconjugation. The term "polyglutamate" refers to the native vitamer and its degree of polyglutamylation without 

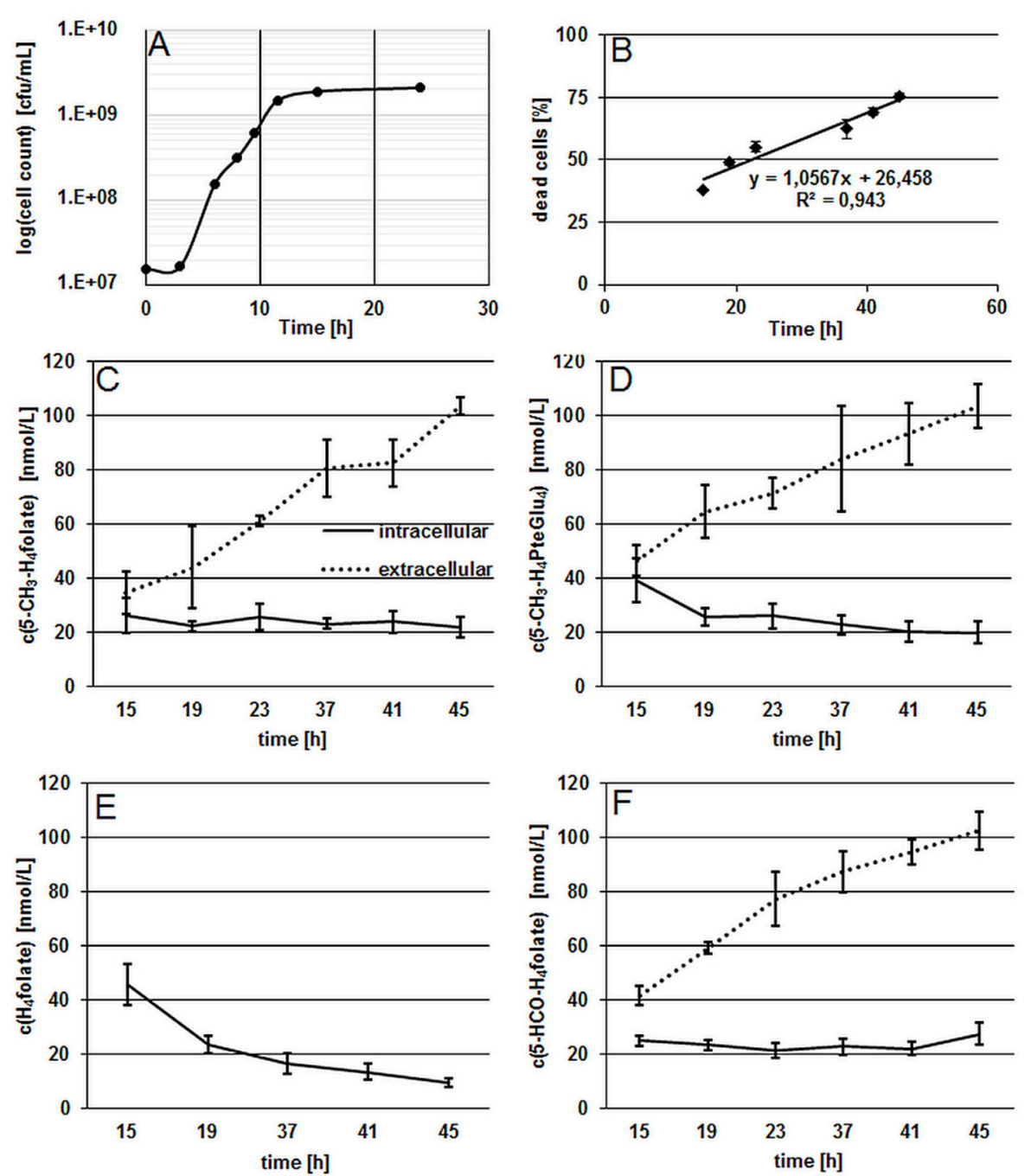

FIGURE 1 | Characterization of growth and folate production in B. adolescentis DSM $20083^{\mathbf{T}}$ during the stationary phase. (A) Growth curve of B. adolescentis DSM $20083^{\top}$ in FFM determined by the drop plate method (cells counted two times), measurement uncertainty $6.1 \%$. (B) Linear increase of dead cells during the stationary phase. (C,D) Intra- and extra-cellular folate concentrations of 5- $\mathrm{CH}_{3}-\mathrm{H}_{4}$ folate (C) and 5- $\mathbf{C H}_{3}-\mathrm{H}_{4} \mathrm{PteGlu} 4 \mathbf{( D )}$ depicted as means of triplicate extraction. (E) Intra-cellular concentrations of $\mathrm{H}_{4}$ folate. (F) Intra- and extra-cellular concentrations of 5- $\mathrm{HCO}-\mathrm{H}_{4}$ folate.

deconjugation. Results of mono- and poly-glutamate analysis are shown in Figures 2A,B.

As there is hardly any difference between the monoand poly-glutamate contents, almost $100 \%$ of $5-\mathrm{CH}_{3}$ $\mathrm{H}_{4}$ folate can be ascribed to $5-\mathrm{CH}_{3}-\mathrm{H}_{4} \mathrm{PteGlu}_{4}$ after 24 $\mathrm{h}$ which is consistent with the results from the steady state experiment (Section Extra- and Intra-cellular Folate Production of B. adolescentis DSM $20083^{\mathrm{T}}$ during the Stationary Phase).

An intracellular amount of $\mathrm{n}\left(5-\mathrm{CH}_{3}\right.$ $\mathrm{H}_{4}$ folate,LC/MS) intracellular $=0.385 \pm 0.059 \mathrm{nmol}$ was determined by LC-MS/MS (Figure 2C). For the extracellular fraction $\mathrm{n}\left(5-\mathrm{CH}_{3}-\mathrm{H}_{4} \text { folate, } \mathrm{LC} / \mathrm{MS}\right)_{\text {extracellular }}=0.461 \pm 0.095$ nmol were determined (Figure 2D). Based on a total amount of $\mathrm{n}\left(5-\mathrm{CH}_{3}-\mathrm{H}_{4} \text { folate, } \mathrm{LC} / \mathrm{MS}\right)_{\text {total }}=0.846 \mathrm{nmol}$ a relative viability of $46 \pm 7 \%$ and a relative mortality of $54 \pm 11 \%$ were calculated from folate analysis (Table 1).

B. adolescentis showed a strong correlation between time and viability in distilled water during cell purification. Therefore, the duration of the washing step $\left(\mathrm{t}_{1}-\mathrm{t}_{0}\right.$, $\left.\mathrm{min}\right)$ between removal of the centrifuged bacteria from the culture $\left(t_{0}\right)$ and fluorescence microscopy $\left(\mathrm{t}_{1}\right)$ was multiplied with the slope of the calibration function $(-0.0865$; Figure S2A). From fluorescence microscopy (Figure S3), which showed good precision with CVs of 3\%, we obtained $52 \pm 3 \%$ viable and $48 \pm 3 \%$ dead cells after correcting for the washing step (Table 1).

These results were multiplied with the sum of 0.846 nmol total folate in the whole culture assay (Figure 2D, Table S2). Finally, comparable amounts were obtained with $\mathrm{n}\left(5-\mathrm{CH}_{3}-\mathrm{H}_{4} \text { folate,calculated }\right)_{\text {intracellular }}=0.426 \pm 0.022 \mathrm{nmol}$ 
extracellular $\mathrm{c}\left(5-\mathrm{CH}_{3}-\mathrm{H}_{4}\right.$ folate $)$ in $\mathrm{FFM}$ [nmol/L]

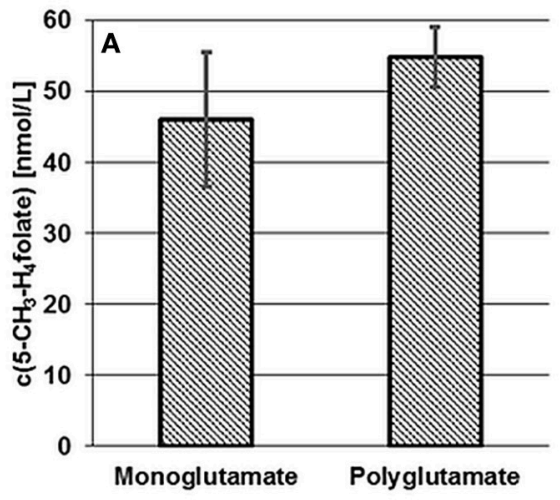

n(5- $\mathrm{CH}_{3}-\mathrm{H}_{4}$ folate) SIDA LC-MS/MS [nmol]

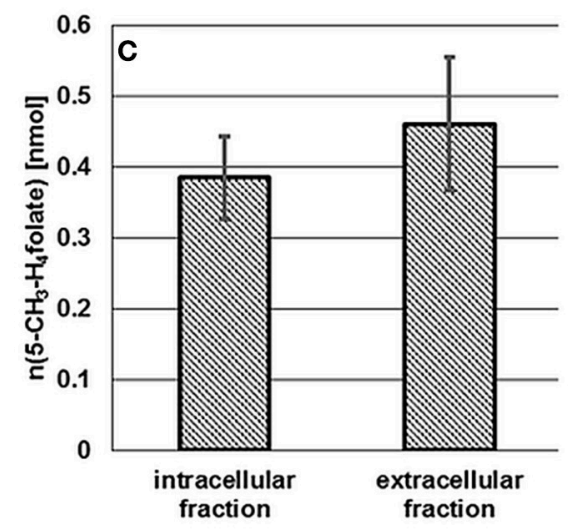

intracellular $\mathrm{c}\left(5-\mathrm{CH}_{3}-\mathrm{H}_{4}\right.$ folate $)$ [nmol/L]

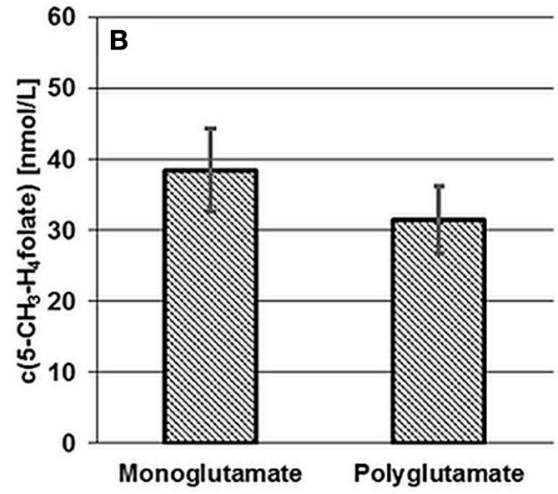

$\mathrm{n}\left(5-\mathrm{CH}_{3}-\mathrm{H}_{4}\right.$ folate) fluorescence microscopy [nmol]

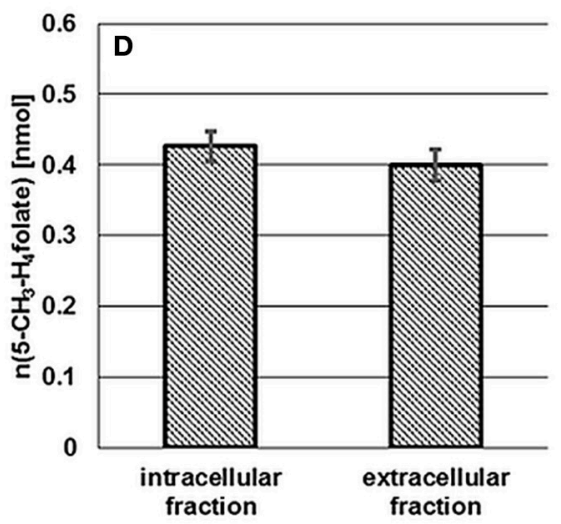

FIGURE 2 | Accumulation and release of $\mathbf{5}-\mathbf{C H}_{3}-\mathbf{H}_{4}$ folate by B. adolescentis DSM $20083^{\mathbf{T}}$. Extra- (A) and intracellular (B) $5-\mathrm{CH}_{3}-\mathrm{H}_{4}$ folate concentrations in cultures of $B$. adolescentis DSM $20083^{\top}$ after $24 \mathrm{~h}$ in FFM. Absolute amount of $5-\mathrm{CH}_{3}-\mathrm{H}_{4}$ folate calculated from SIDA LC-MS/MS (C) and by extrapolation from fluorescence microscopy (D). Data are shown as mean and standard deviations (triplicate experiments).

and $\mathrm{n}\left(5-\mathrm{CH}_{3}-\mathrm{H}_{4} \text { folate,calculated }\right)_{\text {extracellular }}=0.400 \pm 0.022$ nmol. Both methods showed no significant difference of the absolute amount of intra- and extra-cellular $5-\mathrm{CH}_{3}-\mathrm{H}_{4}$ folate.

These results disprove the assumption that $5-\mathrm{CH}_{3}-\mathrm{H}_{4}$ folate is excreted actively by $B$. adolescentis, as it would imply a significant higher proportion of extracellular $5-\mathrm{CH}_{3}-\mathrm{H}_{4}$ folate to total $5-\mathrm{CH}_{3}-\mathrm{H}_{4}$ folate than the ratio of dead cells measured by microscopy. To substantiate these findings, we analyzed folate production by one additional species, $B$. pseudocatenulatum.

\section{Characterization of Folate Production by $B$. pseudocatenulatum DSM $20438^{\top}$}

B. pseudocatenulatum DSM $20438^{\mathrm{T}}$ was examined for intraand extra-cellular 5- $\mathrm{CH}_{3}-\mathrm{H}_{4}$ folate and $5-\mathrm{CH}_{3}-\mathrm{H}_{4}$ PteGlu ${ }_{2-4}$ after $24 \mathrm{~h}$ incubation in FFM. Results of the mono- and poly-glutamate analysis are shown in Figures 3A,B.

$50 \pm 12 \mathrm{nmol} \cdot \mathrm{L}^{-1} 5-\mathrm{CH}_{3}-\mathrm{H}_{4}$ folate and $37 \pm 5.5 \mathrm{nmol} \cdot \mathrm{L}^{-1}$ of the polyglutamylated vitamers were determined in the extracellular fraction (A) whereas the cells contained $64 \pm 7.7$ $\mathrm{nmol} \cdot \mathrm{L}^{-1}$ monoglutamate and $74 \pm 5.0 \mathrm{nmol} \cdot \mathrm{L}^{-1}$ polyglutamate (B). Thus and analogously to B. adolescentis almost $100 \%$ of
TABLE 1 | Relative viabilities obtained from fluorescence microscopy (measured) or SIVA-LC-MS/MS (calculated).

\begin{tabular}{llcc}
\hline Strain & $\begin{array}{l}\text { Relative viability Fluorescence } \\
\text { calculation (\%) }\end{array}$ & microscopy & $\begin{array}{c}\text { Ratio of absolute } \\
\text { amounts } \\
\text { 5- } \mathbf{C H}_{\mathbf{3}}-\mathbf{H}_{\mathbf{4}} \text { folate } \\
\text { intra-/extra-cellular } \\
\text { to total }\end{array}$ \\
\hline $\begin{array}{l}\text { B. adolescentis DSM } \\
\text { 20083 }\end{array}$ & Viable cells & $52 \pm 3$ & $46 \pm 7$ \\
\hline $\begin{array}{l}\text { B. pseudocatenulatum } \\
\text { DSM 20438 }\end{array}$ & Dead cells & $48 \pm 3$ & $54 \pm 11$ \\
& Viable cells & $56 \pm 3$ & $56 \pm 7$ \\
\hline & Dead cells & $44 \pm 3$ & $44 \pm 10$ \\
\hline
\end{tabular}

$5-\mathrm{CH}_{3}-\mathrm{H}_{4}$ folate can be traced back to the tetraglutamate. No significant difference $(P>0.05)$ was found for the mono- and poly-glutamate content.

Based on LC-MS/MS measurements $\mathrm{n}\left(5-\mathrm{CH}_{3}-\right.$ $\mathrm{H}_{4}$ folate, $\left.\mathrm{LC} / \mathrm{MS}\right)_{\text {intracellular }}=0.640 \pm 0.077 \mathrm{nmol}, \mathrm{n}\left(5-\mathrm{CH}_{3}-\right.$ $\mathrm{H}_{4}$ folate,LC/MS) extracellular $=0.495 \pm 0.119 \mathrm{nmol}$ (Figure 3C) 

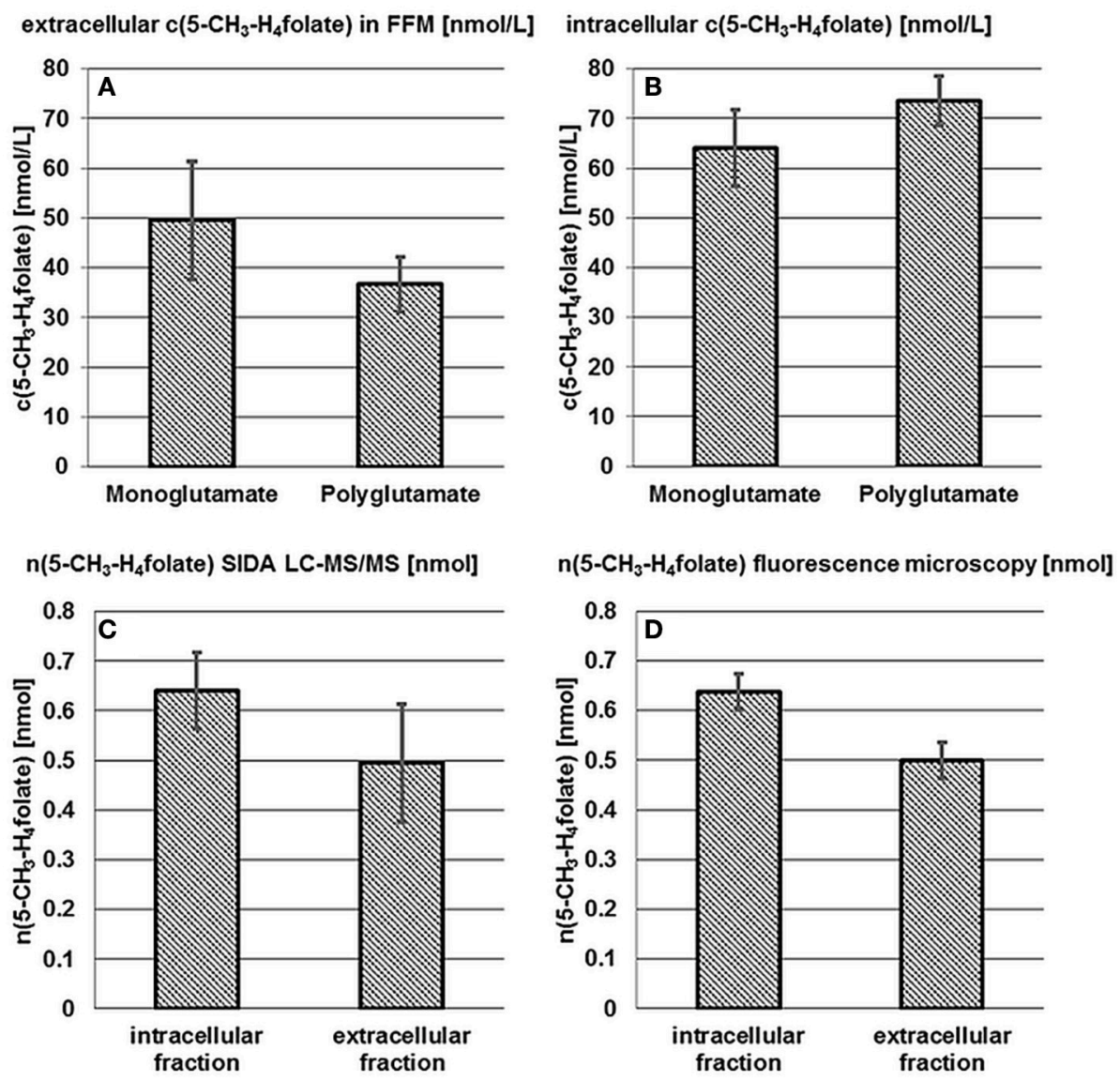

FIGURE 3 | Accumulation and release of 5- $\mathrm{CH}_{3}-\mathrm{H}_{4}$ folate by B. pseudocatenulatum DSM $20438^{\top}$. See Figure 2.

and a total amount of $\mathrm{n}\left(5-\mathrm{CH}_{3}-\mathrm{H}_{4} \text { folate,LC/MS }\right)_{\text {total }}=$ $1.135 \mathrm{nmol}$ were determined for cells, FFM and the sample as a whole, respectively. In analogy to $B$. adolescentis DSM $20083^{\mathrm{T}}$ a relative viability of $56 \pm 7 \%$ and a relative mortality of $44 \pm 10 \%$ was calculated using the LC-MS approach.

A relative, corrected (Figure S2B) amount of $56 \pm$ $3 \%$ viable and $44 \pm 3 \%$ dead cells was determined by fluorescence microscopy. B. pseudocatenulatum formed small cell clusters and cell distribution was less homogenous than observed for B. adolescentis. Nevertheless, CVs for viability and the ratio of dead cells were 3\%. After multiplication of the relative viability with the total amount of 1.135 nmol 5- $\mathrm{CH}_{3}-\mathrm{H}_{4}$ folate (Figure 3D, Table S3) n(5- $\mathrm{CH}_{3}-$ $\mathrm{H}_{4}$ folate,calculated $)_{\text {intracellular }}=0.637 \pm 0.036 \mathrm{nmol}$ and $\mathrm{n}\left(5-\mathrm{CH}_{3}-\mathrm{H}_{4} \text { folate,calculated }\right)_{\text {extracellular }}=0.498 \pm 0.036 \mathrm{nmol}$ were calculated for cellular fraction and FFM, respectively. Both methods showed no significant $(P>0.05)$ difference between the absolute amount of intra- and extra-cellular 5- $\mathrm{CH}_{3}-\mathrm{H}_{4}$ folate.

Compared to the results obtained with $B$. adolescentis, we found an even higher agreement between viable/dead cells and intra-/extra-cellular folate for B. pseudocatenulatum.

\section{DISCUSSION}

Characterization of folate synthesis by bacteria is challenging as analytical methodologies for folate determination differ considerably and imprecision of measurements might lead to a misinterpretation of results.

Our previously developed SIDA LC-MS/MS for detailed assessment of intra- and extra-cellular folate patterns in bifidobacteria (Kopp et al., 2016) showed a high reproducibility for main folate vitamers as well as an accurate quantitation of mono- and polyglutamylated $5-\mathrm{CH}_{3}-\mathrm{H}_{4}$ folate. In the present manuscript, fluorescence microscopy was used for determination of viable/dead cell ratios.

Stationary phase experiments with $B$. adolescentis DSM $20083^{\mathrm{T}}$ revealed equivalent intra- and extra-cellular folate patterns of $5-\mathrm{CH}_{3}-\mathrm{H}_{4}$ folate, depicted by the fact that 5$\mathrm{CH}_{3}-\mathrm{H}_{4}$ folate can be traced back solely to its tetraglutamate. Moreover, 5- $\mathrm{HCO}-\mathrm{H}_{4}$ folate and $5-\mathrm{CH}_{3}-\mathrm{H}_{4}$ folate showed similar intra- and extra-cellular curve progressions with an increasing vitamer concentration in FFM and a constant concentration in the cellular fraction. Nevertheless, $5-\mathrm{HCO}-\mathrm{H}_{4}$ folate has to be regarded as sum of non-methylated folates like $5,10-\mathrm{CH}^{+}$$\mathrm{H}_{4}$ folate, $5-\mathrm{HCO}-\mathrm{H}_{4}$ folate, and $10-\mathrm{HCO}-\mathrm{H}_{4}$ folate being prone 
to interconversion (May et al., 1951; Wilson and Horne, 1983; Brouwer et al., 2007), whereas $5-\mathrm{CH}_{3}-\mathrm{H}_{4}$ folate remains stable. In contrast to $5-\mathrm{HCO}-\mathrm{H}_{4}$ folate and $5-\mathrm{CH}_{3}-\mathrm{H}_{4}$ folate, $\mathrm{H}_{4}$ folate was not detected extracellularly, which might be attributed to its low stability. Intracellular $\mathrm{H}_{4}$ folate decreased significantly under steady state conditions. In growing cells, $\mathrm{H}_{2}$ folate and $\mathrm{H}_{4}$ folate are the first folate vitamers synthesized (Rossi et al., 2011). After folate polyglutamylation functional groups are transferred for essential metabolic reactions like DNA synthesis. The decrease in $\mathrm{H}_{4}$ folate might be attributed to the fact that initially high synthesis rates of $\mathrm{H}_{4}$ folate related to immense growth during the exponential phase are reduced because of a reduced availability of nutritional factors in the medium. $\mathrm{H}_{4}$ folate might be converted to essential biological active folate vitamers as they are necessary to maintain growth during the stationary phase.

Nevertheless, we were able to prove the similarity of intraand extra-cellular folate patterns (criterion 1) by showing that a linear increase in dead cells, followed by an enrichment of $5-\mathrm{CH}_{3}-\mathrm{H}_{4}$ folate in the extracellular fraction can be ascribed to $\sim 100 \% 5-\mathrm{CH}_{3}-\mathrm{H}_{4} \mathrm{PteGlu}_{4}$ whereas the concentration in cells remains constant. Therefore, the hypothesis of active folate excretion seems to be at least partly invalid. In the next experiment, we examined and compared the relative viability from fluorescence microscopy and the analytical approach to prove or disprove criterion (2). In our main experiments with B. adolescentis DSM $20083^{\mathrm{T}}$ and B. pseudocatenulatum DSM $20438^{\mathrm{T}}$, we found no extracellular $\mathrm{H}_{4}$ folate, which is either not excreted or underlies increased degradation in FFM after cell lysis. Because of folate interconversion, $5-\mathrm{HCO}-\mathrm{H}_{4}$ folate seems to be no specific marker as its content reflects the concentration of more than one vitamer. Therefore, we chose $5-\mathrm{CH}_{3}-\mathrm{H}_{4}$ folate as marker compound and determined intra- and extra-cellular concentrations of this vitamer and its polyglutamate patterns. The determination of $5-\mathrm{CH}_{3}-\mathrm{H}_{4} \mathrm{PteGlu}_{2-4}$ revealed $5-\mathrm{CH}_{3}$ $\mathrm{H}_{4} \mathrm{PteGlu}_{4}$ to be the only polyglutamic form released from cells into the medium $(\sim 100 \%)$ after $24 \mathrm{~h}$. Combined with the relative count of viable and dead cells we obtained a significant correlation between viability and absolute amount of intra- and extra-cellular $5-\mathrm{CH}_{3}-\mathrm{H}_{4}$ folate. Because the ratio of the absolute intra- and extra-cellular amounts compared to the total amount produced by the strains is consistent with their relative viabilites after $24 \mathrm{~h}$ cultivation (criterion 2 ), we conclude for $5-\mathrm{CH}_{3}-\mathrm{H}_{4}$ folate that cell lysis is the only determinant for extracellular $5-\mathrm{CH}_{3}-\mathrm{H}_{4}$ folate enrichment in vitro. This conclusion is valid for the sensitivity range of our assay, which would detect mono- and poly-glutamates

\section{REFERENCES}

Brouwer, V., de Zhang, G.-F., Storozhenko, S., van der Straeten, D., and Lambert, W. E. (2007). pH stability of individual folates during critical sample preparation steps in prevision of the analysis of plant folates. Phytochem. Anal. 18, 496-508. doi: 10.1002/ pca.1006

D’Aimmo, M. R., Mattarelli, P., Biavati, B., Carlsson, N. G., and Andlid, T. (2012). The potential of bifidobacteria as a source of natural exceeding $10 \%$ of the total content of all $5-\mathrm{CH}_{3}-\mathrm{H}_{4}$ folate forms extracellularly.

Altogether, the results of the present work refute early findings assuming active excretion of folates by bifidobacteria (Deguchi et al., 1985; Pompei et al., 2007) and imply that $5-\mathrm{CH}_{3}-\mathrm{H}_{4} \mathrm{PteGlu}_{4}$ is released via cell lysis, particularly in the stationary phase of the bacteria culture. This conclusion is further substantiated by the lack of evidence for any mechanisms of transport of polyglutamylated folate vitamers. Intestinal deconjugation of pteroylpolyglutamates is mediated by glutamate carboxypeptidase II (GPC II), a brush border transmembrane glycoprotein located in the proximal part of the jejunum (Reisenauer et al., 1977; Reisenauer and Halsted, 1981; McNulty and Pentieva, 2010). So far GPC II constitutes the only enzyme for pteroylpolyglutamate deconjugation identified in the human gut. Therefore, further experiments have to be performed to clarify the extent of colonic deconjugation which is crucial for colonic uptake of folate, as colonic folate production is assumed to contribute to the host nutritional status.

\section{AUTHOR CONTRIBUTIONS}

MK, KD, MS, TC, and MR designed the studies. MK, KD, and MS developed and validated all methods. MK, KD, MS, and MR interpreted data. TC supervised microbiological experiments. MK, TC, and MR drafted the manuscript. All authors contributed to improvement of the manuscript and agreed with the content. MR had primary responsibility for funding and final manuscript content.

\section{ACKNOWLEDGMENTS}

We thank Sami Kaviani-Nejad and Ines Otte from the Deutsche Forschungsanstalt für Lebensmittelchemie (Freising, Germany) for analytical assistance, Jürgen Behr from the Chair of Technical Microbiology (Freising, Germany) for help with the supervision of KD and MS, and Sarah Just, Caroline Ziegler, and Melanie Kornbauer from the ZIEL Institute for Food \& Health (Freising, Germany) for helpful discussions and technical instructions.

\section{SUPPLEMENTARY MATERIAL}

The Supplementary Material for this article can be found online at: http://journal.frontiersin.org/article/10.3389/fmicb. 2017.00445/full\#supplementary-material folate. J. Appl. Microbiol. 112, 975-984. doi: 10.1111/j.1365-2672.2012. 05261.x

Deguchi, Y., Morishita, T., and Mutai, M. (1985). Comparative studies on synthesis of water-soluble vitamins among human species of bifidobacteria. Biosci. Biotechnl. Biochem. 49, 13-19.

Freisleben, A., Schieberle, P., and Rychlik, M. (2002). Syntheses of labeled vitamers of folic acid to be used as internal standards in stable isotope dilution assays. J. Agric. Food Chem. 50, 4760-4768. doi: 10.1021/jf02 5571k 
Kopp, M., Duerr, K., Steigleder, M., Clavel, M., and Rychlik, M. (2016). Development of stable isotope dilution assays for the quantitation of intra- and extracellular folate patterns of Bifidobacterium adolescentis. J. Chromatogr. A 1469, 48-59. doi: 10.1016/j.chroma.2016.09.048

May, M., Bardos, T. J., Barger, F. L., Lansford, M., Ravel, J. M., Sutherland, G. L., et al. (1951). Synthetic and degradative investigations of the structure of folinic acid-SF. J. Am. Chem. Soc. 73, 3067-3075. doi: 10.1021/ja011 $51 \mathrm{a} 028$

McNulty, H., and Pentieva, K. (2010). "Folate Bioavailability," in Folate in Health and Disease, ed L. B. Bailey (Boca Raton, FL: Taylor \& Francis), 25-47.

Ndaw, S., Bergaentzle, M., Aoude-Werner, D., Lahely, S., and Hasselmann, C. (2001). Determination of folates in foods by high-performance liquid chromatography with fluorescence detection after precolumn conversion to 5-methyltetrahydrofolates. J. Chromatogr. A. 928, 77-90. doi: 10.1016/S0021-9673(01)01129-3

Pompei, A., Cordisco, L., Amaretti, A., Zanoni, S., Matteuzzi, D., and Rossi, M. (2007). Folate production by bifidobacteria as a potential probiotic property. Appl. Environ. Microb. 73, 179-185. doi: 10.1128/AEM.01763-06

Reisenauer, A. M., and Halsted, C. H. (1981). Human jejunal brush border folate conjugase: characteristics and inhibition by salicylazosulfapyridine. Biochim. Biophys. Acta 659, 62-69. doi: 10.1016/0005-2744(81)90271-0
Reisenauer, A. M., Krumdieck, C. L., and Halsted, C. H. (1977). Folate conjugase: two separate activities in human jejunum. Science 198, 196-197. doi: $10.1126 /$ science. 20663

Rossi, M., Amaretti, A., and Raimondi, S. (2011). Folate production by probiotic bacteria. Nutrients 3, 118-134. doi: 10.3390/nu3010118

Shane, B., and Stokstad, E. L. (1975). Transport and metabolism of folates by bacteria. J. Biol. Chem. 250, 2243-2253.

Wilson, S. D., and Horne, D. W. (1983). Evaluation of ascorbic acid in protecting labile folic acid derivatives. Proc. Natl. Acad. Sci. U.S.A. 80, 6500-6504. doi: $10.1073 /$ pnas. 80.21 .6500

Conflict of Interest Statement: The authors declare that the research was conducted in the absence of any commercial or financial relationships that could be construed as a potential conflict of interest.

Copyright $\odot 2017$ Kopp, Dür, Steigleder, Clavel and Rychlik. This is an open-access article distributed under the terms of the Creative Commons Attribution License (CC $B Y)$. The use, distribution or reproduction in other forums is permitted, provided the original author(s) or licensor are credited and that the original publication in this journal is cited, in accordance with accepted academic practice. No use, distribution or reproduction is permitted which does not comply with these terms. 